\title{
PEMANTAUAN DAN PEMBERDAYAAN KADER LANSIA TENTANG ASAM URAT DENGAN MEDIA BODESERA DI WILAYAH KERJA PUSKESMAS MULYOREJO SURABAYA JAWA TIMUR
}

\section{(MONITORING AND EMPOWRMENT OF ELDER CADRES URATIC ACID USING BODESERA MEDIA IN MULYOREJO PUBLIC HEALTH CENTER (PUSKESMAS) SURABAYA EAST JAVA)}

\author{
Lailatun Ni'mah ${ }^{1}$, Ika Nur Pratiwi ${ }^{2}$, Abu Bakar $^{3}$, Laily Hidayati ${ }^{4}$ \\ ${ }^{1,2,3,4}$ Fakultas Keperawatan Universitas Airlangga \\ e-mail: lailatunnimah@fkp.unair.ac.id
}

\begin{abstract}
Gout are nitrogen compounds that result from the process of catabolism (breakdown) of purine from both diet and endogenous nucleic acid (deoxyribonuleic acid DNA). Most of the members of the Posyandu Lansia in the working area of the Mulyorejo Health Center are gout sufferers. These community service activities include: 1) monitored uric acid levels of members of the Posyandu Lansia 2) health education for elderly members and cadres about gout: definition, symptom signs, and gout diet with Bodesera media (Booklets and Models of Uric Acid-Free Healthy Foods) 3) training on how to use gout test kits for elderly cadres and 4) administering gout tests to elderly cadres. The results of the pre-test showed that elderly gout sufferers, and elderly cadres had diverse knowledge about the definition of gout, diet of gout, signs of gout and how to check gout. These results are still at less value, while the results of the post-test assessment indicate that the participants' knowledge has increased. This community service activity is needed to improve understanding of gout in the working area of the Mulyorejo Health Center Surabaya. Community service activities can be carried out regularly so that the health of elderly Posyandu members can be monitored and elderly cadres are able to independently check the acid levels of the elderly.
\end{abstract}

Keywords: gout, elderly, health education

\section{abstrak}

Asam urat, gout, pirai atau arthritis pirai adalah senyawa nitrogen yang dihasilkan dari proses katabolisme (pemecahan) purin baik dari diet maupun dari asam nukleat endogen (asam deoksiribonuleat DNA). Sebagian besar anggota Posyandu Lansia wilayah kerja Puskesmas Mulyorejo adalah penderita asam urat. Kegiatan pengabdian masyarakat ini meliputi: 1) memantau kadar asam urat para anggota Posyandu Lansia 2) pendidikan kesehatan kepada anggota dan kader Lansia tentang asam urat: definisi, tanda gejala, dan diet asam urat dengan media Bodesera (Booklet dan Model Makanan Sehat Bebas Asam Urat) 3) pelatihan cara menggunakan alat tes asam urat kepada kader lansia serta 4) pemberian alat tes asam urat kepada kader lansia. Hasil pretest menunjukkan para lansia penderita asam urat, dan mempunyai pengetahuan yang beragam mengenai definisi asam urat, diet asam urat, tanda asam urat dan cara pemeriksaan asam urat. Hasil tersebut masih berada pada nilai kurang, hasil penilaian posttest menunjukkan bahwa pengetahuan para peserta mengalami peningkatan. Kegiatan pengabdian masyarakat ini diperlukan untuk meningkatkan pemahaman tentang asam urat di wilayah kerja Puskesmas Mulyorejo Surabaya. Kegiatan pengabdian masyarakat dapat dilaksanakan secara teratur agar kesehatan lansia anggota Posyandu lansia dapat terpantau dan kader Lansia mampu mengecek kadar asam lansia dengan mandiri.

Kata kunci: Asam urat, Lansia, Pendidikan Kesehatan 


\section{PENDAHULUAN}

Asam urat, gout, pirai atau arthritis pirai adalah senyawa nitrogen yang dihasilkan dari proses katabolisme (pemecahan) purin baik dari diet maupun dari asam nukelat endogen (asam deoksiribonuleat DNA). Asam urat dalam tubuh sebagian besar dieksresi melalui ginjal dan hanya sebagian kecil melalui saluran cerna (Syukri, 2007). Pirai atau asam urat berhubungan erat dengan gangguan metabolisme purin yang memicu peningkatan kadar asam urat dalam darah (hiperurisemia). Batasan hiperurisemia secara ideal yaitu kadar asam urat di atas 2 standar deviasi hasil laboratorium pada populasi normal (Hidayat, 2009). Kadar asam urat dalam darah normal untuk laki-laki adalah 3-7,2 mg/dL dan kadar asam urat untuk perempuan adalah 2-5,6 mg/dL.

Kejadian gout pada tahun 2008 yang dilaporkan oleh World Health Organization adalah mencapai 20\% dari penduduk dunia. Data Departemen Kesehatan Republik Indonesia tahun 2008 menyatakan bahwa Jawa Timur memiliki 28\% dari 4.209 .817 lansia menderita penyakit gout. Gout merupakan salah satu penyakit yang diderita oleh lansia di Jawa Timur. Berbagai faktor yang berperan untuk terjadinya gout meliputi obat-obatan, penyakit, alkohol, dehidrasi, obesitas, usia, jenis kelamin dan kelaparan. Penyakit gout atau asam urat merupakan hasil metabolisme yang mengalir melalui peredaran darah, jika kadar asam urat terlalu tinggi atau terlalu sedikit yang dibuang melalui air kencing, akan terbentuk kristal-kristal kecil dan akan mengendap pada salah satu persendian hingga menimbulkan rasa nyeri, bengkak di sekitar persendian dan kelainan bentuk sendi. Penyebab pasti gout primer masih belum diketahui, namun penyakit ini dapat disebabkan oleh efek genetik pada metabolisme purin, yang menyebabkan produksi berlebih asam urat atau hiperurisemia, retensi asam urat, dan keduanya. Gout sekunder yang terjadi selama perjalanan penyakit lain seperti diabetes mellitus, hipertensi, anemia sel sabit, dan penyakit renal (Kowalak, Jennifer P, 2011).

Penyakit gout / asam urat banyak terjadi pada usia di atas 55 tahun. Pengaturan diet sehat perlu mendapatkan perhatian khusus pada usia tersebut. Kegiatan pendidikan masyarakat di Posyandu Lansia perlu ditingkatkan kegiatannya khususnya tentang asam urat / gout. Pendidikan kesehatan terhadap lansia dan kader lansia tentang asam urat harus memiliki media pendidikan yang bagus, menarik, mudah dipahami dan mudah diaplikasikan ketika sampai di rumah. Media Bodesera (Booklet, Model Makanan Sehat Bebas Asam Urat) merupakan media yang tepat diterapkan di Posyandu Lansia, khususnya Posyandu Lansia di wilayah kerja Puskesmas Mulyorejo Surabaya.

Salah satu Posyandu Lansia di wilayah kerja Puskesmas Mulyorejo adalah Posyandu Lansia di daerah Kejawan Putih Tambak. Posyandu Lansia tersebut memiliki kegiatan aktif setiap bulan yaitu senam lansia bersama dan pemantauan kadar asam urat setiap bulan. Kegiatan pengabdian masyarakat dengan judul "Pemantauan dan Pemberdayaan Kader Lansia tentang Asam Urat dengan Media Bodesera di Wilayah Kerja Puskesmas Mulyorejo Surabaya Jawa Timur" diharapkan dapat melatih keterampilan kader lansia dan dapat mengetahui status kesehatan para lansia khususnya kadar asam urat dalam darah. Kegiatan pengabmas ini juga diharapkan dapat meningkatkan pemahaman dan pengetahuan lansia tentang diet bebas asam urat yang tepat dan menjadi daya tarik dalam kegiatan Posyandu lansia.

\section{METODE PENGABDIAN MASYARAKAT}

Kegiatan pengabdian masyarakat dilaksanakan pada hari Kamis, tanggal 19 Oktober 2017 di Rumah Kader Posyandu Lansia yaitu Ibu Sita dengan alamat Jl. Kejawan Putih BMA No. 33 Surabaya. Kegiatan ini dilaksanakan dengan kerjasamaa antara Universitas 
Airlangga dengan Puskesmas Mulyorejo Surabaya. Kegiatan ini merupakan kegiatan pengabdian masyarakat yang dilakukan oleh staf pengajar dosen keperawatan medikal bedah Fakultas Keperawatan Universitas Airlangga bersama dengan mahasiswa program regular dan alih jenis berjumlah 9 mahasiswa Fakultas Keperawatan Universitas Airlangga.

Topik yang diberikan disesuaikan dengan hasil analisis situasi dan kebutuhan. Berbagai data diperoleh dari penelitian sebelumnya tentang banyaknya pasien asam urat yang kurang memahami tentang definisi asam urat, diet asam urat dan tanda gejala asam urat. Pelaksanaan kegiatan meliputi: 1) memantau kadar asam urat para anggota Posyandu Lansia 2) pendidikan kesehatan kepada anggota dan kader Lansia tentang asam urat: definisi, tanda gejala, dan diet asam urat dengan media Bodesera (Booklet, Model Makanan Sehat Bebas Asam Urat) 3) pelatihan cara menggunakan alat tes asam urat kepada kader lansia serta 4) pemberian alat tes asam urat kepada kader lansia. Kegiatan ini dihadiri oleh 73 peserta lansia, 8 kader, 4 orang dosen Fakultas Keperawatan dan 9 orang mahasiswa Fakultas Keperawatan Surabaya.

\section{HASIL DAN PEMBAHASAN}

Data yang diperoleh disajikan dalam bentuk tabel, gambar dan narasi. Penyajian hasil dibagi dalam tiga bagian yaitu: 1) Hasil pemantauan kadar asam urat lansia dengan stik tes asam urat, 2) kegiatan pendidikan kesehatan bagi anggota dan kader Lansia tentang asam urat: definisi, tanda gejala diet, asam urat dengan media Bodesera (Booklet, Model Makanan Sehat Bebas Asam Urat) dan 3) Hasil pre-posttest peserta kegiatan.

\section{Kegiatan pemantauan kadar asam urat anggota Posyandu Lansia}

Kegiatan pemantauan ini dilakukan oleh mahasiswa berjumlah lansia 73 lansia. Tidak semua lansia bersedia dilakukan pemantauan kadar asam urat karena takut ditusuk, atau baru saja tes darah lengkap. Sejumlah 3 orang yang tidak mau dicek. Hasil pemantauan sejumlah 70 lansia, sebagian besar lansia memiliki kadara sam urat tinggi yaitu rentang 6,7-9,7 mg/dL. Sebagian kecil lansia kadar asam urat dalam darah memiliki kadar 3,8-5,5 $\mathrm{mg} / \mathrm{dL}$

Kegiatan pendidikan kesehatan bagi anggota dan kader Lansia tentang asam urat: definisi, tanda gejala diet, asam urat dengan media Bodesera (Booklet, Model Makanan Sehat Bebas Asam Urat) Pemateri, pembawa acara dan fasilitator (dosen) pada kegiatan ini terdiri 1) Lailatun Ni'mah, S.Kep., Ns.M.Kep. ; 2) Laily Hidayati, S.Kep.,Ns.,M.Kep.; 3) Dr. Abu Bakar, S.Kep., Ns. Sp. KMB 4) Ika Nur Pratiwi, S.Kep.,Ns.,M.Kep., dan sembilan mahasiswa Fakultas Keperawatan yaitu Dinda Salmahella, Talia Puspita Adianti , Siska Kusuma Ningsih, Firdha Lailil Fadila, Fenny Eka Juniarti, Amira Aulia Robeta Lintang Dwiwardani, Baiq Selly Silviani dan Maria Wahyu M.P.

Booklet berisi materi pendidikan yang meliputi definisi, tanda gejala diet, asam urat diberikan setelah kegiatan pendidikan kesehatan agar peserta pendidikan fokus mendengarkan pemateri. Media Bodesera (Booklet, Model Makanan Sehat Bebas Asam Urat) dipilih agar para peserta mengenal dan mampu mengidentifikasi dengan benar makanan yang boleh dan tidak boleh untuk penderita asam urat. Model makanan dipilih agar peserta tertarik dengan materi dan mendapatkan contoh yang jelas tentang diet bagi penderita asam urat. 


\section{Hasil Evaluasi Kegiatan Pengabdian Masyarakat}

Proses evaluasi (pre test dan post test) pada seluruh peserta edukasi menggunakan lembar pertanyaan yang harus diisi oleh peserta kegiatan. Soal pre test dan post test mencakup materi tentang definisi asam urat, penyebab asam urat, ciri-ciri asam urat, pencegahan asam urat, diet asam urat, pencegahan asam urat. Tabel 1 dapat dilihat bahwa hasil pre test para peserta sebelum diberikan informasi atau penjelasan menunjukkan 60 orang dari peserta $(100 \%)$ memperoleh nilai < 60, yang berarti peserta hanya mampu menjawab kurang dari setengah total pertanyaan yang diajukan. Nilai rerata pada pre test 18,75 . Terdapat 2 orang pada nilai pre test mendapatkan nilai baik dan pada post test nilai keduanya tidak menunjukkan peningkatan yang berarti. Nilai rerata pada post test adalah 41,25 .

Tabel 1 Hasil pre test dan post test Kegiatan Pengabdian Masyarakat Pemantauan dan pemberdayaan kader lansia tentang asam urat dengan media Bodesera di Wilayah Kerja Puskesmas Mulyorejo Surabaya.

\begin{tabular}{|c|c|c|c|}
\hline No. Peserta & Nilai pre test & Nilai post test & $\Delta$ \\
\hline 1 & 49,8 & 83 & 33,2 \\
\hline 2 & 58,1 & 91,3 & 33,2 \\
\hline 3 & 58,1 & 74,7 & 16,6 \\
\hline 4 & 58,1 & 74,7 & 16,6 \\
\hline 5 & 49,8 & 74,7 & 24,9 \\
\hline 6 & 66,4 & 66,4 & 0 \\
\hline 7 & 49,8 & 74,7 & 24,9 \\
\hline 8 & 49,8 & 74,7 & 24,9 \\
\hline 9 & 58,1 & 74,7 & 16,6 \\
\hline 10 & 58,1 & 74,7 & 16,6 \\
\hline 11 & 49,8 & 83 & 33,2 \\
\hline 12 & 58,1 & 91,3 & 33,2 \\
\hline 13 & 58,1 & 74,7 & 16,6 \\
\hline 14 & 58,1 & 74,7 & 16,6 \\
\hline 15 & 49,8 & 74,7 & 24,9 \\
\hline 16 & 49,8 & 66,4 & 16,6 \\
\hline 17 & 74,7 & 74,7 & 0 \\
\hline 18 & 49,8 & 74,7 & 24,9 \\
\hline 19 & 58,1 & 74,7 & 16,6 \\
\hline 20 & 58,1 & 74,7 & 16,6 \\
\hline 21 & 49,8 & 83 & 33,2 \\
\hline 22 & 58,1 & 91,3 & 33,2 \\
\hline 23 & 58,1 & 74,7 & 16,6 \\
\hline 24 & 58,1 & 74,7 & 16,6 \\
\hline 25 & 49,8 & 74,7 & 24,9 \\
\hline 26 & 58,1 & 66,4 & 8,3 \\
\hline 27 & 74,7 & 74,7 & 0 \\
\hline 28 & 49,8 & 74,7 & 24,9 \\
\hline 29 & 58,1 & 74,7 & 16,6 \\
\hline 30 & 58,1 & 74,7 & 16,6 \\
\hline 31 & 58,1 & 83 & 24,9 \\
\hline 32 & 58,1 & 91,3 & 33,2 \\
\hline 33 & 58,1 & 74,7 & 16,6 \\
\hline 34 & 49,8 & 74,7 & 24,9 \\
\hline
\end{tabular}




\begin{tabular}{|c|c|c|c|c|}
\hline & 35 & 74,7 & 74,7 & 0 \\
\hline & 36 & 49,8 & 66,4 & 16,6 \\
\hline & 37 & 49,8 & 74,7 & 24,9 \\
\hline & 38 & 58,1 & 74,7 & 16,6 \\
\hline & 39 & 58,1 & 74,7 & 16,6 \\
\hline & 40 & 49,8 & 74,7 & 24,9 \\
\hline & 41 & 58,1 & 83 & 24,9 \\
\hline & 42 & 58,1 & 91,3 & 33,2 \\
\hline & 43 & 58,1 & 74,7 & 16,6 \\
\hline & 44 & 58,1 & 74,7 & 16,6 \\
\hline & 45 & 49,8 & 74,7 & 24,9 \\
\hline & 46 & 58,1 & 66,4 & 8,3 \\
\hline & 47 & 74,7 & 74,7 & 0 \\
\hline & 48 & 49,8 & 74,7 & 24,9 \\
\hline & 49 & 58,1 & 74,7 & 16,6 \\
\hline & 50 & 58,1 & 74,7 & 16,6 \\
\hline & 51 & 58,1 & 83 & 24,9 \\
\hline & 52 & 58,1 & 91,3 & 33,2 \\
\hline & 53 & 58,1 & 74,7 & 16,6 \\
\hline & 54 & 58,1 & 74,7 & 16,6 \\
\hline & 55 & 49,8 & 74,7 & 24,9 \\
\hline & 56 & 58,1 & 66,4 & 8,3 \\
\hline & 57 & 74,7 & 74,7 & 0 \\
\hline & 58 & 49,8 & 74,7 & 24,9 \\
\hline & 59 & 58,1 & 74,7 & 16,6 \\
\hline & 60 & 58,1 & 74,7 & 16,6 \\
\hline & 61 & 58,1 & 83 & 24,9 \\
\hline & 62 & 58,1 & 91,3 & 33,2 \\
\hline & 63 & 58,1 & 74,7 & 16,6 \\
\hline & 64 & 58,1 & 74,7 & 16,6 \\
\hline & 65 & 49,8 & 74,7 & 24,9 \\
\hline & 66 & 58,1 & 66,4 & 8,3 \\
\hline & 67 & 74,7 & 74,7 & 0 \\
\hline & 68 & 49,8 & 74,7 & 24,9 \\
\hline & 69 & 58,1 & 74,7 & 16,6 \\
\hline & 70 & 58,1 & 74,7 & 16,6 \\
\hline & 71 & 49,8 & 83 & 33,2 \\
\hline & 72 & 58,1 & 91,3 & 33,2 \\
\hline & 73 & 58,1 & 74,7 & 16,6 \\
\hline & $\sum$ & 4166,6 & 5594,2 & 1427,6 \\
\hline & $\mathbf{X}$ & 57,07671233 & 76,63287671 & 19,55616438 \\
\hline \multicolumn{5}{|l|}{ Keterangan: } \\
\hline$\sum \quad$ : Jumlah & & & & \\
\hline : Rerata & & & & \\
\hline : Selisih & & & & \\
\hline
\end{tabular}

Hasil pre test sebelum diberikan pendidikan kesehatan terlihat bahwa para lansia penderita asam urat, dan kader lansia mempunyai pengetahuan yang beragam mengenai 
definisi asam urat, diet asam urat, tanda tanda asam urat dan cara pemeriksaan asam urat. Hal ini dibuktikan dengan hasil pre test yang menunjukkan nilai pengetahuan yang sangat bervariasi, namun masih berada pada nilai kurang, sedangkan pada hasil penilaian post test dapat diketahui bahwa pengetahuan para peserta mengalami peningkatan. Pengetahuan yang dimaksud dalam hal ini definisi, tanda gejala, diet makanan asam urat, komplikasi. meskipun penilaian pengetahuan berdasarkan hasil pre test dan post test bukanlah satu-satunya acuan keberhasilan edukasi.

\section{PENUTUP}

\section{Simpulan dan Saran}

Hasil kegiatan pengabdian masyarakat yang telah dilakukan dapat dilihat bahwa kegiatan pendidikan kesehatan ini diperlukan untuk peningkatan kader dan pemahaman tentang asam urat di wilayah kerja Puskesmas Mulyorejo Surabaya pada aspek definisi asam urat, diet asam urat, cara pencegahan, tanda gejala, komplikasi dan cara mengecek asam urat. Peserta pendidikan menyampaikan bahwa melalui kegiatan ini pengetahuan peserta bertambah, oleh sebab itu peserta dan juga pihak Puskesmas Mulyorejo Surabaya menginginkan agar kegiatan pengabdian masyarakat dapat terus dilakukan secara rutin khususnya untuk evaluasi kegiatan secara berkesinambungan dan kontinyu. Para kader lansia juga mampu mengecek kadar asam urat secara mandiri kepada anggota Posyandu lansia. Rencana tindak lanjut yang akan dilakukan oleh tim adalah terus melakukan pemantauan dan evaluasi untuk keberlanjutan edukasi yang telah dilakukan dan memberikan informasi lain yang berkaitan dengan Asam urat.

\section{DAFTAR PUSTAKA}

Aini, F 2010, 'Pengaruh Pendidikan Kesehatan Reproduksi Remaja Melalui Media Booklet Terhadap Perubahan Pengetahuan dan Sikap Santri Tentang Kesehatan Reproduksi di Pesantren Darul Hikmah dan Ta'dib Al Syakirim di Kota Medan Tahun 2010', Skripsi, Medan: Universitas Sumatera Utara.

Hidayat, R. 2009. "Gout dan Hiperurisemia". Devisi Reumathologi Departemen Ilmu Penyakit Dalam. Vol. 22, no 1. Jakarta: Graha Ilmu

Kowalak, P. Jennifer., 2011. Buku Ajar Patofisiologi. Jakarta: EGC.

Syukri M. 2007. “Asam Urat dan Hiperuresemia”. Majalah Kedokteran Nusantara Volume 40 No. 1 Maret 2007 